\title{
声門閉鎖に関する実験的研究
}

\author{
渡邊宏・岩 永 康 成・梅 崎 俊 郎
}

\section{Glottic Closing Pressure During Deglutition in Recurrent Laryngeal Nerve Paralysis}

\author{
Hiroshi Watanabe, Yasunari Iwanaga and Toshiro Umezaki
}

\begin{abstract}
The glottic incompetence caused by recurrent laryngeal paralysis results in not only voice problem but also occasional aspiration. Injections of silicon or collagen have been effectively used to improve the voice of paralysis cases. A transcutaneous intrafold injection technique in which the needle is inserted into the vocal fold through the thyroid lamina under fiberoptic monitoring has been employed in our clinic. There have been few reports on the effect of intrafold injection upon aspiration. In the present study, we measured the glottic closing pressure during swallowing in 12 normal cats and 19 cats with recurrent laryngeal nerve paralysis. In paralytic animals, measurements were conducted before and after silicon injection. A micro-tip catheter pressure transducer (Model PC-330, Micro-Tip, Miller Co. Ltd.) was employed. The results indicate that silicon injection can increase the glottic closing pressure up to the level enough to avoid aspiration.
\end{abstract}

Key words：声門閉鎖圧，ネコ，誤燕，反回神経麻痺

$$
\text { は じめに }
$$

声帯レベルに限って言えば，声門閉鎖不全で嗄声が生じ ても，誤嚥を生じる率はほんの僅かである。一般的には反 回神経麻痺症例の中で約10\%程度とされている.

今回我々が報告するネコと反回神経麻疩患者に対して行っ た一連の実験系は，声門閉鎖のみが誤嚥に関与する割合を， 反回神経切断ネコを使ってできるだけ定量的に抽出しょう と，試みた結果である。すなわち，鱟下に際しての，喉頭 挙上, 喉頭蓋の倒れ込み運動などの付帯条件を除外した声 門閉鎖圧のみで，反回神経麻痺単独あるいは下咽頭収縮筋 の嚥下に関与する割合を測定することにその系のポイント をおいたことにある。

本実験系では，嚥下が起こっても micro-tip 圧トランス ジューサの受圧部が移動する事なく，さらに声門下圧の同 時記録が可能である．声帯内シリコン注入のみが実際にど の程度誤嚥を防止しうるか，これは興味ある課題である。

\section{実 験 方 法}

反回神経麻瘏の際にみられる誤嚥は，声門閉鎖不全によ るものと考えられている。そこで麻酔ネコ喉頭を用いて， 声門閉鎖圧の直接測定を行った。一側反回神経麻痺の急性 期と慢性期での閉鎖圧の測定結果を比較するとともに，声 带内にシリコン注入を行い, 声門閉鎖圧の改善の程度を検
討した.

実験 : 実験にはネコを用い, 塩酸ケタミン麻酔後気管切 開を行い，T字型カニューレを気管に固定. cannula につ けたガイドチューブより, Millar社製 “mikro-tip” catheter transducer (Model PC-330, Micro-Tip, Millar Co. Ltd., Texas）を気管内に導き，ナイロン糸で声帯膜様部 中央に固定した。閉鎖圧は $0.5 \mathrm{ml}$ の咽頭注水により惹起さ れる声門閉鎖圧を本法により測定した。また別個に上喉頭 神経を露出切断して，その末梢端を $40 \mathrm{~Hz}$ 連続刺激による 嚥下運動と，100Hzの 3 発刺激による反射性声門閉鎖を惹 起させ，その記録をおこなった。嚥下惹起に関しては嚥下 の開始は甲状舌骨筋の筋放電を，その指標とした。また cannulaにもう一方向に圧 transducer (Nihon Kohden Co. Ltd., Tokyo, Japan）を付け, 声門下圧の同時測定 を行った（図 1).この工夫は嚥下による喉頭の挙上運動 が声門閉鎖圧に影響されるのを極力避けるためのもので transducer も嚥下と同時に上下し，その喉頭との位置関 係は絶えず同一条件下に保たれる利点がある。これらの現 象は polygraph に導き, magnetic tape recorder と penwriting recorder に記録した。

問題点 : 米国 Millar 社のマイクロチップトランスジュー サは，体外計測式トランスジューサ特有の catheter whip 等のアーチファクトや計測誤差を解決するために開発され ている，そのため周波数特性の優れた圧力センサーをカテー 
テル先端に装着することにより, センサー部での圧力の直 接測定が特徵とされる.さらに体外式トランスジューサで 問題となる時相と振幅のズレを消滅せしめる. 但し温度特 性 $\left(23-38^{\circ} \mathrm{C}\right)$ は $\pm 1 \mathrm{mmHg}$ ，12時間ドリフトは最大 6 $\mathrm{mmHg}$ である。喉頭と cannula の位置関係は transducer が気管を通り声門へ来ていて，常に transducer の sensor 部が声帯膜様部中央に位置するように工夫した。

期間：12匹の急性実験では一側反回神経切断直後に閉鎖 圧を測定したそその後，9 匹の急性ネコ（controlでの嚥 下時声門閉鎖圧の測定後 1 側反回神経を切断）にシリコン 注入し再度閉鎖圧の測定を行った。次いで反対側の反回神 経を切断し，その閉鎖圧を測定した。10匹の慢性実験では， 一側反回神経切断後 1 ケ月以上経過したネコで，たたしそ のほとんどが 3 ケ月を経過したものであったが，急性実験 と同様の実験を行った。ただし，10匹のうち4 匹は慢性実 験直前には声帯位は発声と嚥下に都合の良い正中位にうま く移動していたため，これらのグループは除外した。

次いで，3 人の反回神経麻痺患者で嚥下時の声門閉鎖圧， 発声時の声門閉鎖圧，嚥下時の声門下圧，発声時の声門下 圧の測定を順におこなった。これは，ネコの実験と違って， 気管孔も存在せず，声門下圧用トランスジューサの気管内 装着も不可能であったため, 順にネコに使用した同機種の Millar 社製 Micro-Tip transducerを挿入して, 次々に 測定していった. control 群として正常声帯を有する 2 名 の成人男性で同様の測定を行った．測定に際しては図 2 の ように喉頭ファイバーのチャンネル孔を介して, transducerの受圧部を損傷しないように, 慎重に, 先端より挿入 した状態で，明視下に声帯膜様部に位置するように受圧部 を声門間に保持した。

\section{結果および考察}

甲状腺腫瘍で気管前壁を一部合併切除した場合には，一 時的な声門下圧の低下は誤嚥を生じる場合が多い. 図 3 は こういった症例でファイバースコピー下に声門下より，嚥 下時の唾液の気管内への䛊吸引が観察される。しかし, 二 次的に気管再建を行ったころより徐々に誤與燕は消失した (図 4). 誤嚥を防ぐためには喉頭の解剖学的見地からは, 喉頭蓋, 仮声帯, 声帯と 3 つのピンチコックがあるが, 声 帯の内転運動による air tight な気密性と声門下の陽圧帯 が存在せねばならないのか. 声帯の内転度はどの程度の強 さで声門を閉鎖し，誤嚥を防ごうとするのか.

一般に反回神経麻痺に伴って生じる誤嚥は約 $10 \%$ 程度と されている1,2). 進は反回神経麻痺症例のなかで自覚的に 誤嚥を訴えた14例に実際に食道透視を行ってみて，気管内 にハイトラストを誤悪した症例は 5 例 $(35.7 \%)$ であった と報告している゙ .さらにこれらの結果を踏まえて考察し, 反回神経麻痺に伴って生じる誤嚥のメカニズムとして，1） 声門閉鎖不全 : 健側声带の代償が不充分な場合，および患 側声帯の萎縮が強い場合，2）声門閉鎖不全および喉頭挙 上障害の合併：これは臨床的にはあまり見られず特殊な例，

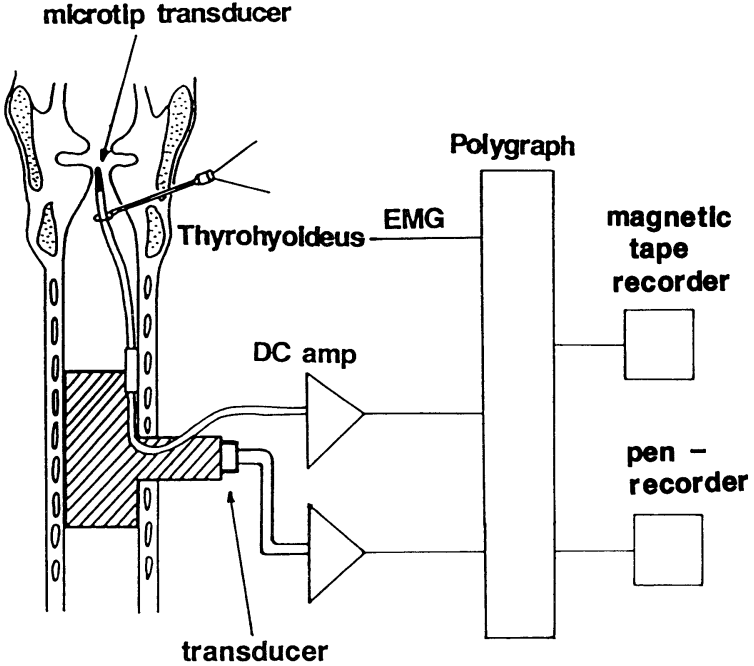

図1 ネコ生理実験モデルのブロック図. catheter pressure transducer の先端受圧部はしっ かりと声带膜様部に固定され, 頻回の嬿下運動に際し ても，決して変位することはない.

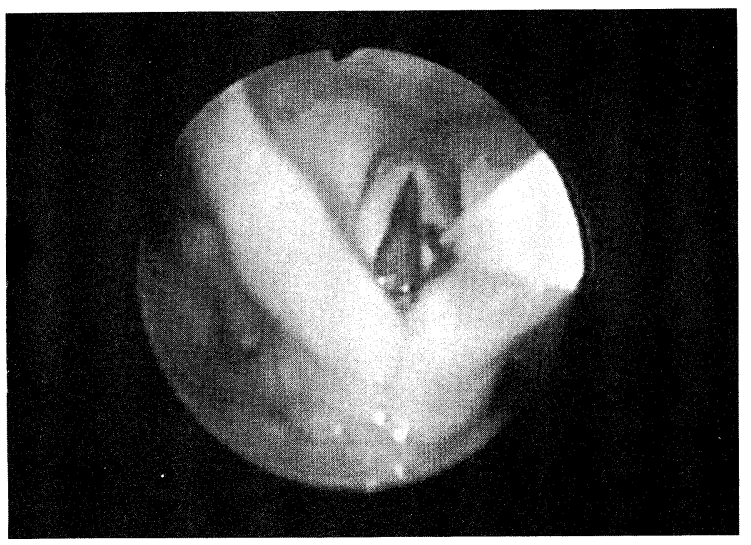

図2 ファイバーのチャンネル孔を介して，明視下にtransducer を声帯膜様部に導くようにした. 写真の中で右 方より Micro-Tip transducer が声帯膜様部の声門 間部に挿入されようとしている.

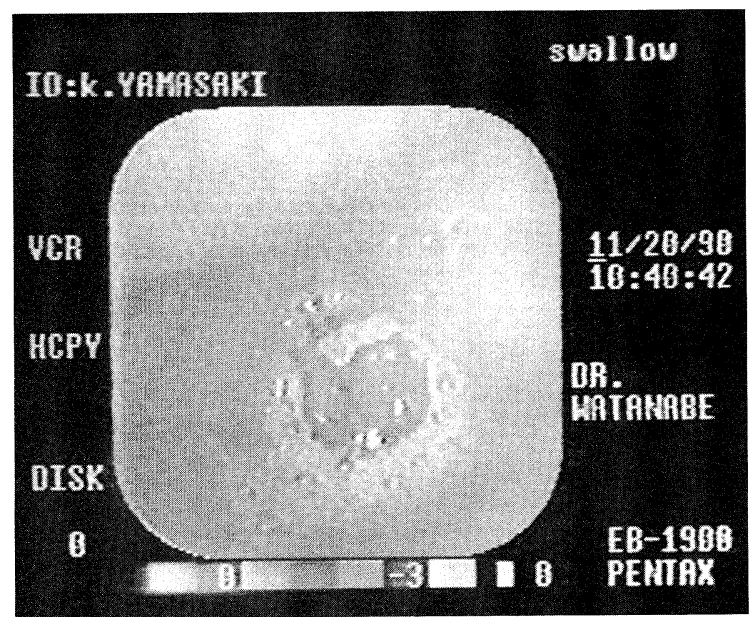

図3 気管孔を介して，声門下圧低下時の甲状腺手術術後患 者の声門下よりの観察像. 嚥下時にこのように唾液の 気管内への流入が認められる. 
3 ) 迷走神経（反回神経および上喉頭神経）および他の脳 神経（IX，XI， XII）麻痺の合併：嚥下筋群の麻痺による嚥 下圧の減弱など，4）喉頭の知覚障害 : 末梢知覚受容器の 機能不全による嚥下反射の減弱の 4 項目を列挙している. 一方牛尾 ${ }^{4)}$ は甲状腺手術の際，やむなく一側反回神経を切 断した19症例についてファイバースコピーによる詳細な検 討を行っている. その結果，誤嚥が残存した症例は 5 例 (26.3\%) であり，䛊燕を生じたがその後治癒した症例は 5 例 $(26.3 \%)$ であった。初めに述べたような徐々に発症 する，すなわち代償作用が声門部に何らかの形で貢献する 反回神経麻瘏症例全体の統計（誤嚥率は約 $10 \%$ ）とは異な り，甲状腺手術症例の場合に䛮嚥を生じる率が大きいのは うなずける。いずれにせよ村上 ${ }^{5)}$ が指摘するように，燕下

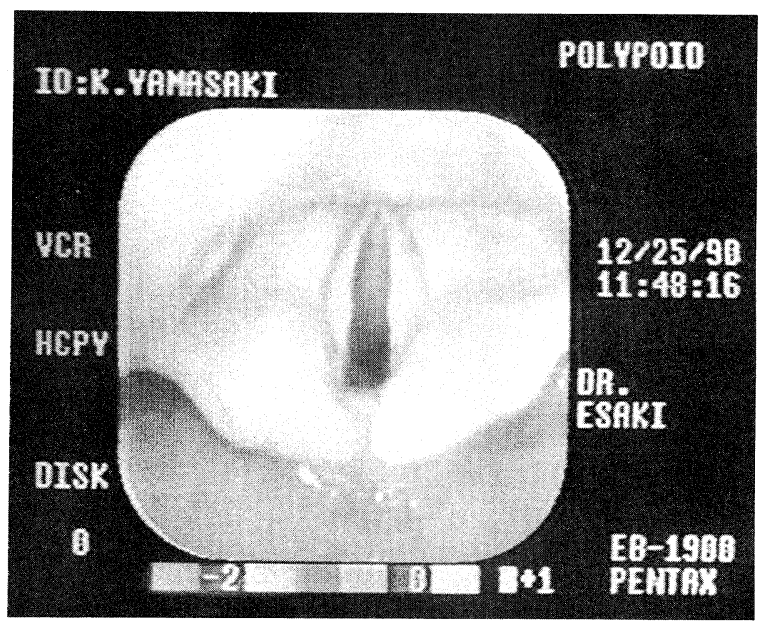

図4四 3 より約 1 ケ月を経過した喉頭像.

嚥下に際しても誤嚥は無い。このころには二次的な気 管再建術が終了している.

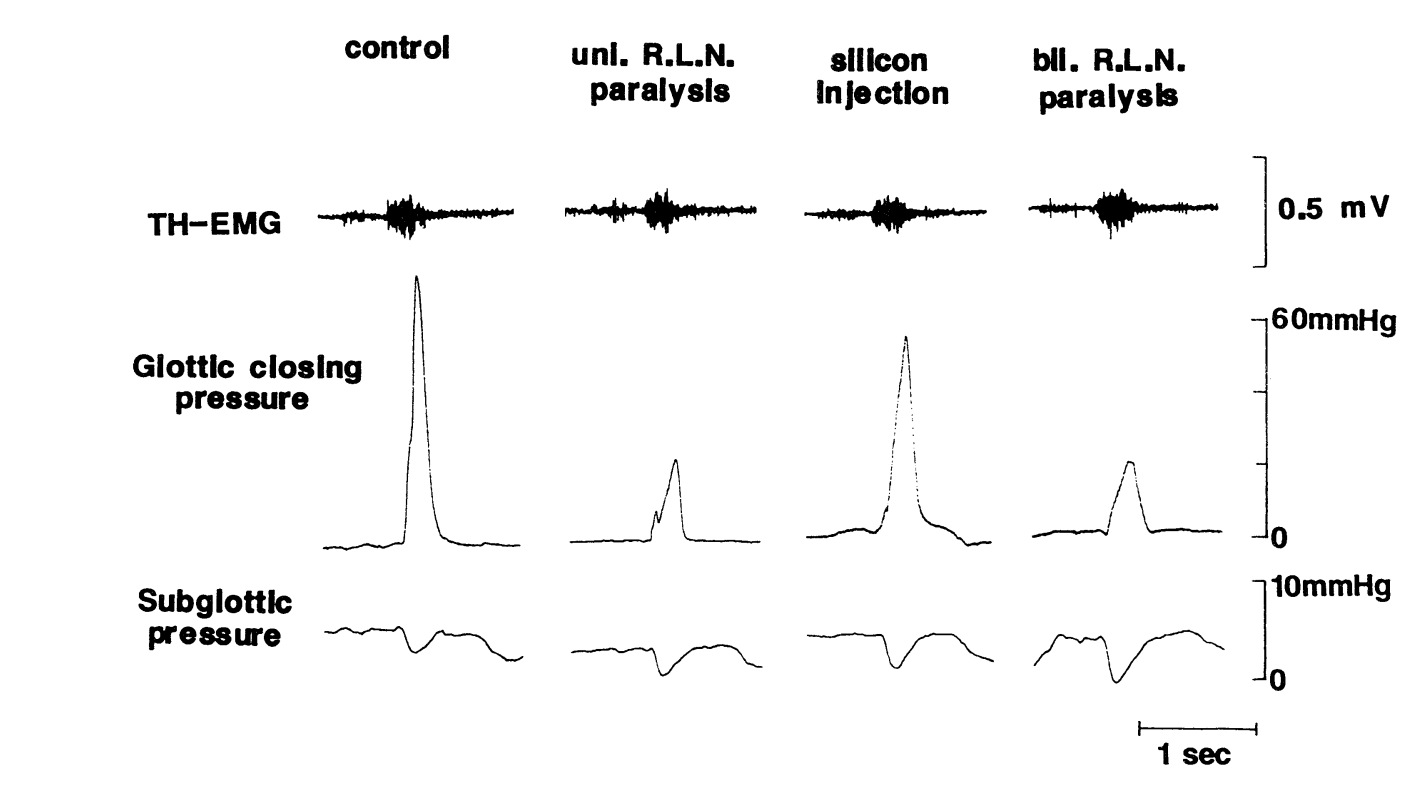

第 II 期が正しく行われるためには，1）呼吸が一時停止す ること，2）声門閉鎖が起こること，3）喉頭全体が前上 方へ挙上すること，4）喉頭蓋が声門を覆うこと，5）下 咽頭収縮筋が弛緩して食道入口部が開くこと，6）これら が一連の協調運動 (co-ordination) として統制 (synergism) されていること，が必要でありこれらのどれに障害があっ ても䜩下の円滑化を欠くであろう.

さて音声学的見地より反回神経麻痹に対する治療に関し ては，声帯内注入療法，披裂軟骨内転術，甲状軟骨形成術 など多数の工夫と報告がなされてきている．声帯内注入療

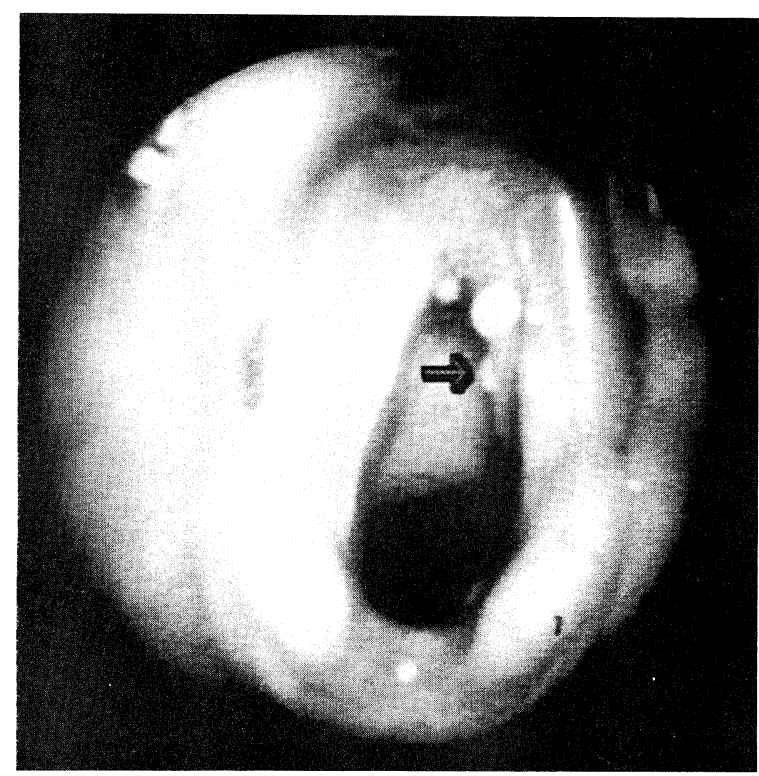

図 5 ネコ声門を直達鏡下に観察している.

Micro-Tip transducer は正しく右膜様部声帯中央に 留置されている (矢印の部位).

図 6 ネコでの control, 左右反回神経切断, シリコン注入, さらに右反回神経切断の燕下時声 門閉鎖圧におよほす影響と，同時に行った際の声門下圧の同時記録結果を示す。 
法に関してはパラフィン, テフロン, シリコン, RTVS (room temperature vulcanized silicone), コラーゲン, アテロコラーゲン（トロポコラーゲンから抗原性のあるテ ロペプチドをペプシン処理した可溶性コラーゲン), ゼ ルフォルム（Gelfoam）などを使用した多数の報告例が ある ${ }^{6 \sim 10)}$ 。ところがこれを嚥下障害症例で声門閉鎖不全に その主な原因があると考えられる場合, 実際に声帯内注入 療法を抗こなって, さてどの程度の効果が得られるもので あろうか.

図 5 は実際にネコで, 声門閉鎖圧を測定途中で, transducer の受圧部が正しく右声帯膜様部に留置されていることを直 達鏡下に確認出来ている（矢印の部位）.

図 6 はネコでの與燕下運動の指標として甲状舌骨筋の筋放 電をモニターしながら, 順に反回神経, 下咽頭収縮筋を切 断していったものである. 正常の声門閉鎖圧は68.0 10.5 $\mathrm{mmHg}$ であった。1 側反回神経切断では嚥下時閉鎖圧は $32 \%$ にまで低下した $(22.0 \pm 3.6 \mathrm{mmHg})$. しかし次の両側 切断では多少の圧の低下も有為な差としては認められず, しかし同様の実験系を使っておこなった実験データで下咽 頭収縮筋を切断すると（この図には無い。進ほかの論文 参照 ${ }^{11)}$ ) 著明に圧の低下を生じた。つまり1側と両側の反 回神経切断ではあまり閉鎖圧に差を生じないこと，急性期 では反回神経麻痺と咽頭収縮筋麻痺は共に同程度に閉鎖圧 に影響することが解った。進ほかの同一の実験条件下では control 圧（初圧）が今回の実験データより低い（57.5 $6.0 \mathrm{mmHg}$ ). そのため 1 側の反回神経切断による閉鎖圧の 減少は約 $36 \%$ であった。しかし何れの実験值も有為な差と しての圧の減少であった。この初圧 (control 群) の違い は, 進ほかはネコを prone positioningにて, 生理的状態 に近い顎, 喉頭, 頸部の屈曲した状態での注水嚥下であっ
たのに比べ, 本実験では supine positioning の状態で声 門に過剩な刺激が加わったものであろう。図6では一旦神 経切断で低下した閉鎖圧はシリコン注入で有意に圧の上昇 をきたしている。

図 7 はヒトでの実験結果である. 嚥下と発声の際の声門 閉鎖圧を測定したものである，左から燕下時の正常閉鎖圧， 1 側反回神経麻痺症例（慢性期）の燕下時閉鎖圧，続いて 発声時正常閉鎖圧, 最後は 1 側反回神経麻痺症例の発声時

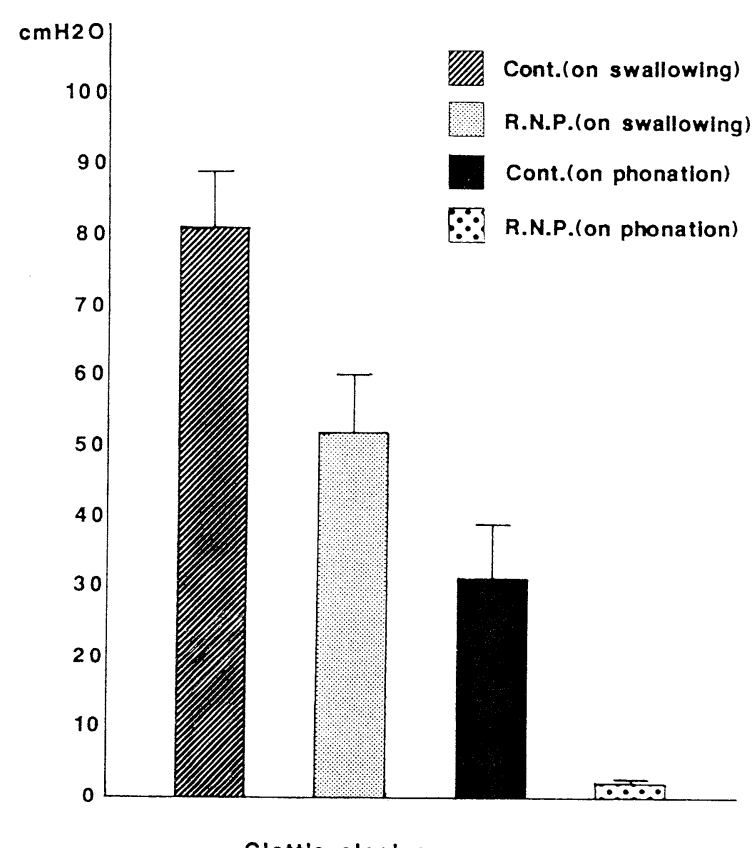

Glottic closing pressure

図7ヒトでの声門閉鎖圧を各々嚥下時, 発声時について記 録したもの. 反回神経麻盘症例は 3 人共に 1 側麻瘏で あり, control 群との対比ずけをおこなった。

\section{unl. R.L.N. paralysis}

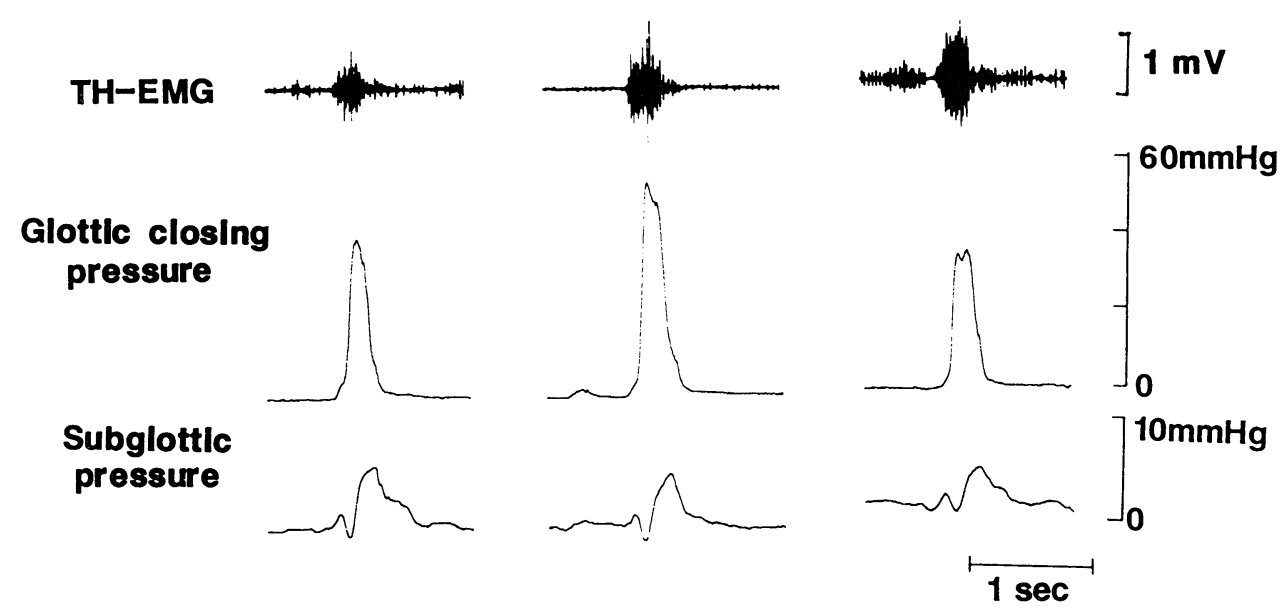

図 81 側反回神経切断後 3 ケ月を経た慢性実験用ネコでのシリコン注入の効果を声門閉鎖圧の変 化として測定したもの. 
閉鎖圧を示す。さきほどの急性期ネコの場合と違って，ヒ トでは発声と嚥下共に有意な差を生じ，つまり言い替えれ ば，シリコン注入は発声ばかりでなく臙下にも有効である ことになる．以下に実際のヒトでの実験值を示す。 control: (on swallowing) glottic closing pressure : $81.2 \pm 7.9 \mathrm{cmH}_{2} \mathrm{O}$. control: (on phonation) glottic closing pressurre: $31.5 \pm 8.2 \mathrm{cmH}_{2} \mathrm{O}$. recurrent nerve paralysis: (on swallowing) glottic closing pressure : $52.0 \pm 8.1 \mathrm{cmH}_{2} \mathrm{O}$. recurrent nerve paralysis: (on phonation) glottic closing pressure: $2.3 \pm 0.8 \mathrm{cmH}_{2} \mathrm{O}$.

図 8 は 1 側反回神経切断後 3 ケ月経過の慢性ネコによる シリコン注入結果である。鱟下による圧変化を観察してい る. 健側声帯の代償機能による初圧の上昇にも拘らず，六 コでも, シリコン注入によって，嚥下圧は有意に上昇した。 ところで, ネコの急性実験と慢性実験とを比較してみると, 一側反回神経麻痺時において, 慢性実験ネコの方が $5 \%$ 以 下の危険率で閉鎖圧は有意に高く, 健側声带の代償機能に よる閉鎖圧の上昇と考えられた。

$$
\text { ま と め }
$$

嚥下時と発声時では下咽頭収縮筋である甲状咽頭筋や輪 状咽頭筋ですら，筋活動様式はまったく異なる，燕下時の 声門閉鎖圧に関しては，声帯麻痺が生じた場合，下咽頭収 縮筋の代償作用が大きいとはいえ, ネコでの反回神経切断 実験で，閉鎖圧が急激に短時日のうちに低下を示すものは 誤曣に影響を拉よぼすことが解った。逆に，こういった症 例に対してファイコンやアテロコラーゲンの注入は誤嚥防 止に有効であることが解った。アテロコラーゲンなどはそ の後, 徐々に吸収されるとはいえ，その間には充分な嚥下 の学習効果 (swallowing rehabilitation) が確立されて しまっているものとおもわれる。
文献

1）野副 功ほか：反回神経麻痺の臨床的研究. 耳鼻 18 : 411 417, 1972.

2）矢野原邦生ほか：反回神経麻痺の臨床像。耳鼻臨床 $71:$ 1201 1207, 1978.

3）進武幹ほか：反回神経麻痺における誤嬩.耳鼻 31 : 416 420, 1985.

4）牛尾浩樹：反回神経麻痖の臨床的並びに実験的研究一 第 1 編 臨床編（その 2 ）誤嬩と反回神経麻㾝.日 外会誌 $82 ： 1307 \sim 1312,1981$.

5）村上 泰：嚥下第二相障害の病態生理と治療. 日気 食会報 $27: 362 \sim 366,1976$.

6）丘村 熙ほか：麻痺声帯のコラーゲン注入.JOHNS $6: 132 \sim 136,1990$.

7）都築 達ほか：声带内シリコン注入術後の長期観察. 耳鼻臨床 83：601～605, 1990 .

8）高山悦代ほか：Vocal Rehabilitation としての声带 内アテロコラーゲン注入術。日気食会報 $41 ： 196$ 201, 1990.

9）丘村 熙ほか：音声外科とアテロコラーゲン注入療 法. 耳喉頭頸 62：117 123，1990.

10) Crumley $R:$ Teflon Versus Thyroplasty Versus Nerve Transfer: A Comparison. Ann Otol Rhinol Laryngol 99: 759 763, 1990.

11) Takemoto $S$, Umesaki $T$ et al: Glottic closure during swallowing in the recurrent laryngeal nerve-paralyzed cat. Otolaryngol-Head and Neck Surg 100: 187 194, 1989.

別刷請求先 $\mathbf{\top} 849$ 佐賀市鍋島 5 丁目1-1 佐賀医科大学耳鼻咽喉科学教室 渡邊 宏 